\title{
What Does—and Does Not-Ail State Constitutional Law
}

Jeffrey S. Sutton ${ }^{*}$

\section{INTRODUCTION}

Open a course catalog at most law schools in the country, and you will find a course called "Constitutional Law." If you happen to take that course, as indeed you must at most of these law schools, you will find one thing more - that it teaches just one side of the story, focusing on the Federal Constitution, rarely mentioning, if mentioning at all, the constitutions of the fifty states.

Why is that? In one sense, the most essential sense, state constitutional law is no less a form of American constitutional law than federal constitutional law. State constitutions, like the Federal Constitution, provide a blueprint for government, allocating authority among the branches of power, establishing the terms of office, and defining the terms of consent. State constitutions, no less than the Federal Constitution, thus establish charters of government that simultaneously empower and constrain: that set forth the rules for regulating the people of a state and limit this authority through liberty, property, structural, and other guarantees. In this sense, state constitutional law parallels federal constitutional law, doing everything the Federal Constitution does, just on a smaller scale.

Just? The difference between the size of the territories covered by the one constitution and the other fifty no doubt helps to explain why state constitutional law is taken less seriously, why some might even ask whether state constitutional law amounts to "constitutional law" at all. But does scale alone provide the answer? Some state constitutions after all cover massive territories and populations themselves. In population, California would be the thirty-fourth largest country in the world, ${ }^{1}$ and

* Judge, United States Court of Appeals for the Sixth Circuit.

1. See Country Comparison: Population, CIA WORLD FACTBOOK (2011), available at https://www.cia.gov/library/publications/the-world-factbook/rankorder/2119rank.html; State \& County Quickfacts: California, U.S. CENSUS BUREAU, http://quickfacts.census.gov/qfd/states/ 06000.html (last visited Apr. 28, 2011). 
Texas, whose people do not take this kind of thing lightly, would be the forty-eighth largest country in the world. ${ }^{2}$ Taken together, more to the point, the fifty constitutions cover all of the land mass and population covered by the United States Constitution, save for a few territories and a conspicuous district, providing a second set of constitutional powers and constraints that touch nearly every American.

Scale, then, must be a partial answer, not a complete one. Else, the greatest constitution of all might be the Charter of the United Nations. Scale alone does not explain why most Americans do not know they live in a state with its own constitution. ${ }^{3}$ It does not explain why so few law schools teach state constitutional law. ${ }^{4}$ Why still fewer of the top-ranked law schools teach the subject. ${ }^{5}$ Why so few states place the topic on their bar exams. ${ }^{6}$ And it does not explain why many newly minted lawyers, licensed to practice law by individual states, not the United States, do not know what it means when they swear to uphold the Federal Constitution and their state constitution. ${ }^{7}$

At least four other features of state constitutional law, it seems to me, diminish it in the eyes of the legal profession: the undue length of most state constitutions; the ease with which they may be amended; the election of judges who interpret them; and lockstep interpretations of the state constitutions with the Federal Constitution. The point of this essay is to examine each critique-dignifying some, responding to others-and to place them all in the broader context of American constitutionalism.

\section{The CONTENT AND LENGTH OF StATE Constitutions}

As a matter of appearance, state constitutions do not look the part. Too many of them are cluttered with provisions having little to do with the architecture of government and more to do with the kinds of

2. See Country Comparison, supra note 1; State \& County Quickfacts: Texas, U.S. CENSUS BUREAU, http://quickfacts.census.gov/qfd/states/48000.html (last visited Apr. 28, 2011).

3. John Kincaid, State Court Protections of Individual Rights Under State Constitutions: The New Judicial Federalism, 61 J. STATE Gov’T 163, 169 (1988); see also Jeffrey S. Sutton, Speech, Why Teach—and Why Study—State Constitutional Law, 34 OKLA. CiTY U. L. REV. 165, 169 (2009); Robert F. Williams, State Constitutional Law: Teaching and Scholarship, 41 J. LEgAL EdUC. 243, 243 (1991).

4. See Sutton, supra note 3, at 166-67.

5. See id. at 167.

6. See id. at $167-68$.

7. See E. Norman Veasey, Foreword to Randy J. Holland, Stephen R. McAllister, JefFrey M. Shaman \& JefFrey S. SutTon, State Constitutional LaW: THE Modern EXPERIENCE, at iii (2010). 
everyday concerns covered by legislation. First impressions make a difference, and a first glance at most state charters suggests a state code, not a state constitution. All state constitutions contain the essentials of structure and rights, and a few of them admirably restrict themselves to the basics - take the constitutions of Missouri, New Hampshire, and Virginia. ${ }^{8}$ But these few exceptions highlight the norm that most state constitutions diminish the essentials of governing by associating them with page after page of laws that amount to nothing more than legislation dressed up in constitutional garb. And often exotic legislation at that. Consider these state constitutional provisions: obligating the government to promote the sale of catfish; ${ }^{9}$ phasing out the use of gill nets in fishing; ${ }^{10}$ authorizing the operation of four casinos and regulating how they must be run, including the parcels of property where they must be located; ${ }^{11}$ mandating "the protection of livestock against the introduction or spread of pleuro pneumonia, glanders, splenetic or Texas fever”; ${ }^{12}$ addressing the "manner of filling vacancies on the Morgan County Board of Education"; ${ }^{3}$ allowing the legislature to regulate the inspection of cattle; ${ }^{14}$ and providing grounds for divorce. ${ }^{15}$

Not just the appearance that state constitutions regulate a remarkable array of subjects, but its prosaic reality, lessens state constitutions. At the founding, the average state constitution contained roughly 7000 words. ${ }^{16}$ Yet today, state constitutions average 36,000 words in length, four times the length of the Federal Constitution. ${ }^{17}$ The Alabama Constitution has 287 sections and 827 amendments, ${ }^{18}$ and the California Constitution has more than 200 sections. $^{19}$ As of 2010, the states have held 233 constitutional conventions and generated more than 7000 constitutional amendments. ${ }^{20}$

8. See J. Harvie Wilkinson III, Gay Rights and American Constitutionalism: What's a Constitution for?, 56 DUKE L.J. 545, 571 (2006).

9. Ala. CONST. amend. 492, § 1.

10. CAL. CONST. art. 10B, § 3-5.

11. OHIO CONST. art. XV, § 6 .

12. IDAHO CONST. art. XVI, § 1.

13. Ala. CONST. amend. 577.

14. TEX. CONST. art. XVI, § 23.

15. S.C. CONST. art. XVII, § 3.

16. HOLLAND ET AL., supra note 7, at 894.

17. State Constitutions, TeXAs POLITICS, http://texaspolitics.laits.utexas.edu/7_3_1.html (last visited Apr. 28, 2011).

18. See ALA. CONST., available at http://alisondb.legislature.state.al.us/acas/ACASLogin Fire.asp.

19. See CAL. CONST., available at http://www.leginfo.ca.gov/const-toc.html.

20. Neal Devins, How State Supreme Courts Take Consequences Into Account: Toward a State- 
In contrast to the sparing elegance of the United States Constitution, which has generated just twenty-seven amendments and which lacks "the prolixity of a legal code,"21 state constitutions look like yard sales, filled with items that never should have been included in the first place and that obscure the basics of governing. There seems to be a tendency to constitutionalize anything that matters a lot to this or that group, "to enshrine every value" they "hold dear,"22 to demonstrate its value by establishing that it is protected not just by law but by supreme law. Yet governmental charters that constitutionalize everything run the risk of constitutionalizing nothing, of inflating away the value of establishing fundamental laws in the first place.

More than just aesthetics, then, is at risk. The undiscriminating range of topics in most state constitutions runs the risk not just of disfiguring them but of undermining the dignity of the charters, of leading the legal academy, to say nothing of the public, not to "tak[e] state constitutions seriously." 23 No one to my knowledge defends this feature of the states' constitutions. But there is an explanation.

\section{The EASE OF AMENDing StATE CONSTITUTIONS}

Most state constitutions look the way they do because their contents depend on the restraint of just fifty-one percent of a state's voters. In contrast to the United States Constitution, which requires three-quarters of the states to ratify any proposed change to it, a mere majority of the electorate may amend the constitutions of forty-seven states. ${ }^{24}$ While Article V stands sentinel against efforts to change the United States Constitution, the majoritarian nature of the states' amendment procedures invites rather than discourages alteration, even in the context of guarantees designed to protect the individual from a democratic majority.

What good is a liberty guarantee or a measure designed to protect discrete groups of citizens if both are one statewide initiative away from

Centered Understanding of State Constitutionalism, 62 STAN. L. REV. 1629, 1640 (2010); see also Peter J. Galie \& Christopher Bopst, Changing State Constitutions: Dual Constitutionalism and the Amending Process, 1 HOFSTRA L. \& POL'Y SYMP. 27, 52 (1996).

21. See McCulloch v. Maryland, 17 U.S. (4 Wheat.) 316, 407 (1819).

22. Wilkinson, supra note 8, at 558.

23. G. Alan TARR, Understanding State Constitutions 2 (1998); see also Devins, supra note 20 , at 1642 .

24. See Council of State Governments, Book of the States 2010, at 13 (2011), available at http://knowledgecenter.csg.org/drupal/system/files/Table_1.2.pdf [hereinafter BoOK OF THE STATES]. The exceptions are the constitutions of Delaware, Florida, and New Hampshire. Id. 
being changed by a majority vote? "Since all state law is reduced to one level," "we no longer have any [state] constitutional law," 25 making state constitutional rights "more akin to statutory rights than to constitutional constraints." 26 This is not the constitution of Brown v. Board of Education, ${ }^{27}$ and indeed it may be the kind of constitution that made Brown necessary. It is why a leading scholar gives just two, not three, cheers for state constitutional law, regretting that "state court decisions interpreting the state constitution to advance liberty or equality can be undone through the electoral process." 28 And it is central to other critiques of state constitutional law. ${ }^{29}$

Doubtless, there is something to this "persistent" charge ${ }^{30}$ that constitutions work best when they block changes to their terms, not when they facilitate them. But is the charge overstated or at least worthy of examination? Start with the amendment dilemma. Setting rules for reforming a document meant to last but not to fall into desuetude is no easy task. As Madison acknowledged, one must "guard[] equally against that extreme facility, which would render the Constitution too mutable; and the extreme difficulty, which might perpetuate its discovered faults."31 It seems unlikely that Jefferson, who thought a constitutional convention should be held every twenty years or so, ${ }^{32}$ would have

25. Margaret C. Klinglesmith, Amending the Constitution of the United States, 73 U. PA. L. REV. 355, 371 (1925); Galie \& Bopst, supra note 20, at 29.

26. Tom Ginsburg \& Eric A. Posner, Subconstitutionalism, 62 STAN. L. REV. 1583, 1606 (2010).

27. 347 U.S. 483 (1954).

28. Erwin Chemerinsky, Two Cheers for State Constitutional Law, 62 STAN. L. REv. 1695, 1701 (2010).

29. See, e.g., Galie \& Bopst, supra note 20, at 29 ("State modes of constitutional reform are usually pointed to as ... making it too easy to effect constitutional change."); Marvin Krislov \& Daniel M. Katz, Taking State Constitutions Seriously, 17 CORNELL J. L. \& PUB. POL'Y 295, 337-38 (2008) (“[V]irtually every state requires mere majority support to ratify a constitutional change.”); Michael G. Colantuono, Comment, The Revision of American State Constitutions: Legislative Power, Popular Sovereignty, and Constitutional Change, 75 CAL. L. REV. 1473, 1475 (1987) ("[C]onstitutional law cannot protect individuals from the majority if the majority can (and does) refashion constitutional law at will.”); Andrew E. Faust, Comment, Pennsylvania's Voluntary Confession Amendment: Majoritarian Control of Fundamental Rights, 89 DiCK. L. REV. 1003, 1027 (1985) (stating that amending a constitution should "require[] more farsightedness and concern for political minorities than legislators usually display in the ordinary course of their majority-bound business").

30. Galie and Bopst, supra note 20, at 29.

31. The Federalist No. 43, at 278 (James Madison) (Clinton Rossiter ed., 1961); see also Galie \& Bopst, supra note 20, at 27.

32. In a letter to Samuel Kercheval, dated July 12, 1816, Jefferson said:

Let us provide in our Constitution for its revision at stated periods. What these periods should be, nature herself indicates. By the European tables of mortality, of the adults living at any one moment of time, a majority will be dead in about nineteen years. At the 
thought that an amendment procedure that has generated just fifteen amendments since his generation left us has answered the risk of deadhand control. ${ }^{33}$

Both the state and federal constitutions, it is well to consider, may imperfectly balance the competing interests between reform and stability, "between timelessness and timeliness." 34 If the state constitutions are too easy to amend, perhaps the Federal Constitution is too hard to amend. ${ }^{35}$ While there is much to admire about the steadfastness of a regime in which nearly 10,000 proposed amendments have been presented to Congress since 1789 and all but twenty-seven of them resisted, ${ }^{36}$ not everyone says a nearly unalterable charter is a virtue. Some worry that provisions have "become[] irrelevant when needed change and rectification of mistakes becomes all but impossible" due to the supermajority requirements for ratification. ${ }^{37}$ Some worry about the pressure placed on the United States Supreme Court to reset the document, to make it relevant to modern disputes through interpretation, ${ }^{38}$ which "risks . . . putting a singular power, a Framer's pen, in the hands of five sitting Justices." 39 Some critics, indeed, charge that "[t]he difficulty of amending that Constitution has led to a regime dominated by non-Article V constitutional change." 40 Others worry that many anti-democratic, but clearly worded, features of the United States Constitution make little

end of that period then, a new majority is come into place, or, in other words, a new generation. Each generation is as independent as the one preceding, as that was of all which had gone before. It has then, like them, a right to choose for itself the form of government it believes most promotive of its own happiness; . . . and it is for the peace and good of mankind, that a solemn opportunity of doing this every nineteen or twenty years, should be provided by the constitution.

HOLLAND ET AL., supra note 7, at 893.

33. After the Bill of Rights was ratified in 1791, the Eleventh Amendment was ratified in 1798, and the Twelfth Amendment was ratified in 1804, no amendments were made until the Civil War Amendments in 1865, 1868, and 1870. See ChARles A. SHANOR, AMERICAN Constitutional LAW: STRUCTURE AND RECONSTRUCTION, at xxxiv-xxxvii (4th ed. 2009).

34. Joseph Blocher, Reverse Incorporation of State Constitutional Law, 84 S. CAL. L. REV. 323, 357 (2011).

35. See Donald S. Lutz, Toward a Theory of Constitutional Amendment, in RESPONDING TO IMPERFECTION: THE THEORY AND PRACTICE OF CONSTITUTIONAL AMENDMENT 237, 265 (Sanford Levinson ed., 1995) [hereinafter RESPONDING TO IMPERFECTION] (observing that the Federal Constitution “is unusually, and probably excessively, difficult to amend”).

36. Galie \& Bopst, supra note 20, at 32.

37. Id. at 28-29.

38. Id. at 28; see also 1 BRUCE ACKerman, We the PEOPle: Foundations 47-50 (1991); Jack M. Balkin \& Sanford Levinson, Understanding the Constitutional Revolution, 87 VA. L. REV. 1045, 1067-68 (2001).

39. Jeffrey S. Sutton, The Role of History in Judging Disputes About the Meaning of the Constitution, 41 TEX. TECH L. REV. 1173, 1180 (2009).

40. Galie \& Bopst, supra note 20, at 28. 
sense in modern America, leaving the gauntlet of the amendment or convention processes as the only solutions. ${ }^{41}$

True or not, these critiques of the Federal Constitution suggest that if the amendment procedures of the state constitutions are too democratic, that is a flaw of degree, not of kind. To say that state constitutions are too amenable to change is to acknowledge a reality of all constitutionsthat rules for reform are maddeningly difficult—and to acknowledge that the state constitutions generally err on one side, but not the only side, of the dilemma. ${ }^{42}$ To the extent the state and federal amendment procedures imperfectly balance the competing interests in stability and progress, they each err in the right direction. Far better, it would seem, to have a nearly immutable national charter and variable state charters than to have the reverse.

Even granting the full force of the majoritarian critique, the state amendment procedures are not monolithic. Consistent with the complexity of the task at hand, the states use a variety of mechanisms, some easier than others, yet all of them undermining the notion that there is just one path to constitutional reform. ${ }^{43}$

The most commonly invoked model of revision is the legislative initiative. $^{44}$ Of all state amendments between 1964 and 1993, legislative initiatives prompted ninety percent of them. ${ }^{45}$ These initiatives typically require approval by the state legislature followed by popular ratification. ${ }^{46}$ States generally use legislative initiatives for limited changes, and some states prohibit their use for more extensive amendment. $^{47}$ At least three states-Delaware, Florida, and New

41. See, e.g., SANFORD LEVINSON, OUR UndEMOCRATIC CONSTITUTION: WHERE THE Constitution Goes Wrong (AND How We the PeOPle CAN CoRrect IT) 167-68 (2006) (criticizing, among other things, the anti-democratic nature of the electoral college, the nonproportional representation of U.S. senators, the life tenure of federal judges, and the difficulty of the amendment process). Professor Akhil Amar questions whether a federal constitutional convention would demand supermajority approval—suggesting that, at least when it comes to federal and state constitutional conventions, both sets of documents may be majoritarian. See Akhil Reed Amar, Popular Sovereignty and Constitutional Amendment, in RESPONDING TO IMPERFECTION, supra note 35, at 89, 89-90 (noting that a constitutional convention with majority support could amend the Federal Constitution).

42. See Galie \& Bopst, supra note 20, at 32 ("Whereas states have preferred to turn ordinary legislation into constitutional amendments, the Congress has preferred to turn potential constitutional amendments into legislation.”).

43. See id. at 27 ("An examination of the modes of constitutional revision at the state level reveals a remarkably diverse and active reform tradition.”).

44. Id. at 32 .

45. Id.

46. Id. at 32,34

47. Id. at 34 . 
Hampshire-not unlike the national government, impose supermajority requirements on the commencement of legislative initiatives. ${ }^{48}$ Delaware requires two-thirds approval by the legislature in two succeeding sessions. $^{49}$ New Hampshire requires two-thirds approval of the legislature, while Florida requires three-fifths approval of it, after which each measure goes to the people for a majority vote. ${ }^{50}$ Delaware stands alone in allowing amendments by legislative initiative that do not require popular ratification. ${ }^{51}$

Of the state amendment procedures, the legislative initiative is not only the most frequently used, but it is also "the least controversial" because it customarily requires legislative and popular approval, ensuring that reforms made this way are "likely to have the support of significant political forces in the state."52 At least when it comes to this procedure, no one can say that it takes the same effort to amend the constitution as it does to change a statute-that state constitutional law and state legislation are one.

Constitutional conventions, generally used to achieve system-wide reform, account for the second highest number of amendments. ${ }^{53}$ While the national government has not held a constitutional convention since 1787, the states have held more than 230 as of $2009 . .^{54}$ In all states, a majority or supermajority vote determines whether the work of a constitutional convention will become law. ${ }^{55}$ Fourteen states even require that the electorate periodically be given a chance to vote-again by a majority ${ }^{56}$ - on whether to convene a new constitutional convention. ${ }^{57}$

Despite concerns about runaway conventions or capture by singleinterest groups, "[a]n examination of the proposals originating from these conventions provide[s] little or no support for the view that state constitutional conventions constitute a danger to the values that comprise the American constitutional tradition." " "The empirical evidence...

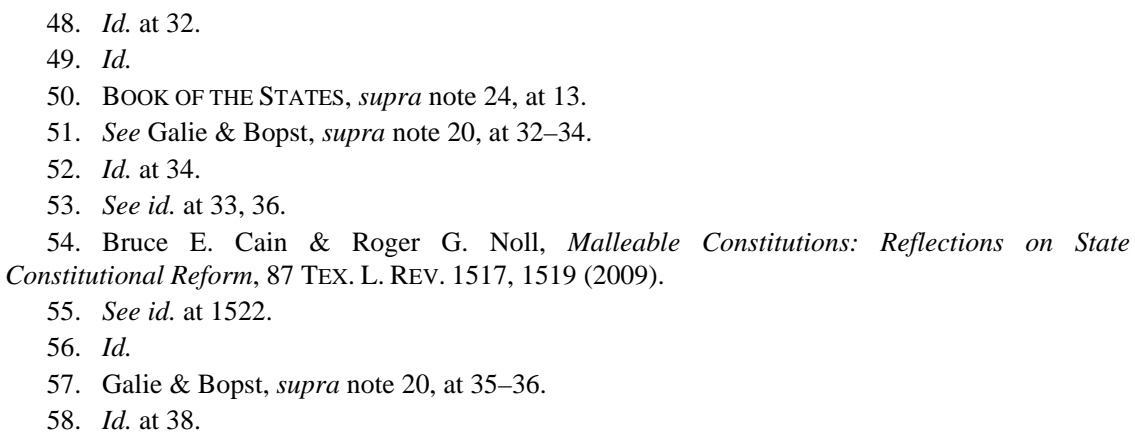


makes it clear that any convention functions within very effective practical limitations." "59 If too much democracy is a perceived problem when it comes to constitutional conventions, the state experiences have not borne that out. "[T]he proposed revisions which have been approved are fairly characterized as moderately progressive and have generally been applauded as valuable improvements over the status quo."60

Many states use constitutional commissions, which perform a variety of roles. Some commissions merely study the state's constitution, reporting data but making no recommendations. ${ }^{61}$ Others collect information and prepare recommendations in advance of constitutional conventions to assist the convention delegates. ${ }^{62}$ Still others propose constitutional revisions to be submitted to the legislature or the voters. ${ }^{63}$ Roughly two-thirds of the states used constitutional commissions in one way or another between 1971 and 2001. ${ }^{64}$ Because any recommendations made by constitutional commissions require approval by the legislature or the voters, and usually both, this device does not amount to an independent form of constitutional revision but an added procedure designed to smooth the path to constitutional reform.

When critics speak of unduly frequent constitutional revisions or, less charitably, of "amendomania," 65 they usually mean the last method of reform: the popular initiative. First adopted by South Dakota in $1898,{ }^{66}$ and initially conceived of as a progressive reform, the initiative is used by just over a third of the states to approve constitutional amendments. ${ }^{67}$ But "nowhere is the practice of government by voter initiative as extreme as it is in California." ${ }^{68}$ After serving for many years on the California Supreme Court, and after observing how the initiative has contributed "to the ease with which California's Constitution can be_-and regularly is_amended," Chief Justice George

59. Id. at 39 (quoting VERNON O'ROURKE \& DOUGLASS CAMPBELL, CONSTITUTION-MAKING in A DeMOCRACy: THEORY AND PRACTICE IN NEW York STATE 26 (1943)).

60. Id. at 40 .

61. Id. at 42 .

62. Id. at $42-43$.

63. Id. 43-44.

64. Peter J. Galie \& Christopher Bopst, The Constitutional Commission in New York: A Worthy Tradition, 64 ALB. L. REV. 1285, 1316 (2001).

65. See Faust, supra note 29, at 1019.

66. S.D. Const. art. III, $\S 1$; see also M. DANE Waters, Initiative AND REFERENDUM Almanac 12 (2003); Ronald M. George, Keynote Address, 62 StAN. L. ReV. 1515, 1516 (2010).

67. Galie \& Bopst, supra note 20, at 46 ("Eighteen states permit the proposing of amendments by popular initiative.”).

68. George, supra note 66, at 1516; see also HoLLAND ET AL., supra note 7, at 927-30. 
lamented that the process is "dysfunctional," often turns solely on whether a proposal is sufficiently well-funded, and has "result[ed] in the perpetual instability of California's state constitutional law."69 Others echo this criticism of direct democracy as applied to all states that use it. $^{70}$

Rather than take sides on this debate, let me instead accept the charges as true-for argument's sake-and try to place them in context. A minority of states use this procedure, and thus only a minority of states run the risk of suffering from it. To the extent this type of reform contains structural deficiencies, as Chief Justice George warns, there is no reason to think that it is beyond the people of the affected states to listen to, appreciate, and eventually even respond to the pitfalls. In this sense, a fifty-one percent tipping point for amending a state constitution is as much an ally as an obstacle to reform, particularly structural reform. And if, for one reason or another, a majority of a state's citizens do not want to change such a pivotal method of reform, it is fair to ask whether they deserve - or at least have decided to embrace - the alleged "chaos" that results. ${ }^{71}$ So far, as it turns out, roughly sixty percent of Californians still respect decisions made by voters through the initiative process more than decisions made by the governor and legislature. ${ }^{72}$

Not just Californians have a chance to experiment with and, if need be, alter the initiative process, but so do the residents of other states. Justice Paul Pfeifer of the Ohio Supreme Court recently called for reforms of the Ohio Constitution, which also permits constitutional initiatives. $^{73}$ He complained that the Ohio Constitution was too long, encumbered by too many non-fundamental provisions, warning that

69. George, supra note 66, at 1516, 1518.

70. See, e.g., Michaele L. Ferguson, Initiatives, Referenda, and the Problem of Democratic Inclusion: A Reply to John Gastil and Kevin O'Leary, 78 U. CoLO. L. REV. 1537, 1538-39 (2007) (" $[\mathrm{W}]$ hile initiatives and referenda are taken to be forms of direct democracy, moneyed interests frequently play a significant role in acquiring the signatures necessary to put an initiative on the ballot, in crafting the language of the legislation, and in campaigning for or against particular measures.”); Susan P. Fino, A Cure Worse Than the Disease? Taxation and Finance Provisions in State Constitutions, 34 RUTGERS L.J. 959, 982 (2003) ("[T]he initiative has become a tool of special interests with money to spend and axes to grind.”).

71. See Elizabeth Garrett, Democracy in the Wake of the California Recall, 153 U. PA. L. REV. 239, 272 (2004) (noting that "judges are wary of direct democracy and of unusual political arrangements that seem chaotic or dangerous"); Kimon Valaskakis, The Perils of "Dumb" Democracy, 13 WIDENER L. REV. 295, 302 (2007) (explaining that direct democracy "could result in major chaotic results given the lack of sophisticated political information and the volatility of public opinion”).

72. George, supra note 66, at 1519.

73. See Alan Johnson, Pfeifer: Revise Constitution, End Death Penalty, Columbus Dispatch, Jan. 20, 2011, at 1B. 
"[Ohio doesn't] want to end up like California, adding things all the time."74 When it comes to the rules for constitutional reform, as opposed to the weather, Ohioans remain free to pick the model they want, a timerespected virtue of federalism.

Many of the eighteen states that permit constitutional initiatives also place limitations on them. ${ }^{75}$ Some place certain topics off limits: Mississippi excludes its Bill of Rights from the procedure; Illinois allows only initiatives related to "the legislative article"; and Massachusetts precludes the initiative from affecting its Declaration of Rights, the judiciary, or issues concerning religion. ${ }^{76}$ The states also limit the procedure by requiring not-insignificant numbers of signatures before an initiative goes on the ballot: Arizona requires fifteen percent of all votes cast in the last election for governor, while Oklahoma requires fifteen percent of votes cast in the race receiving the highest number of votes. ${ }^{77}$ California requires eight percent of all votes cast for governor in the last gubernatorial election. ${ }^{78}$ Half of the affected states ensure that the initiative relates to a statewide concern, not a local one. Typical of this last restriction is Florida, which demands signatures from eight percent of the votes cast in the last presidential election in at least half of the congressional districts. ${ }^{79}$ Still other restrictions exist. In Nevada, an initiative must receive majority support in back-to-back general elections. ${ }^{80}$ A few states require some measure of legislative approval even for popular initiatives. ${ }^{81}$ And the state constitutions' single-subject

74. Id.; see also Ed Golder, Voters Take Law into Own Hands-Ballot Issues Bypass Legislature, But Is That a Good Thing?, GRAND RAPIDS PREss, Oct. 29, 2006, at A1 (quoting the executive vice president of the Michigan Chamber of Commerce saying, "We don't want to end up like California, where people have to stand in the voting booth and guess about the fiscal impact or the meaning of one ballot proposal after another after another.”); Steven Greenhut, Op-Ed., Careful What You Wish For: Some Powerful Players Want to Overhaul the California Constitution. What Could Go Wrong with That?, ORANGE COUNTY REG., June 14, 2009, available at 2009 WLNR 15599355 (discussing candidate Meg Whitman's proposal to reform California's initiative process as part of a constitutional convention).

75. Galie \& Bopst, supra note 20, at 46, 49-51.

76. Id. at 51 .

77. Id.

78. CAL. CONST. art. II, § 8(b); see also George, supra note 66, at 1520.

79. Galie \& Bopst, supra note 20, at 51.

80. Id.

81. See William B. Fisch, Constitutional Referendum in the United States of America, 54 AM. J. CoMP. L. 485, 494-97 (2006). After Massachusetts citizens collect sufficient signatures for a constitutional initiative, at least twenty-five percent of two successive legislatures must approve it. See MASS. CONST. amend. art. XLVIII, pt. IV, § 4. Even with only one-quarter support required, this procedure "has proven quite difficult to navigate" with only three initiatives getting to the ballot in eighty-seven years, two of which passed. Fisch, supra, at 495. The Kansas Constitution provides for amendment by referendum, but only after two-thirds of the total members of each legislative 
requirements generally prohibit placing more than one initiative on the same ballot at a time. ${ }^{82}$

While many initiatives address individual rights, the states have not been one-sided in addressing them. Galie and Bopst report that, between 1970 and 1986, the states passed seventy-six legislative initiatives amending their constitutions, and "40 were rights restrictive and 36 rights enhancing., ${ }^{, 83}$ Between 1986 and 1990, this pattern continued with "20 restrictive and 19 expansive measures adopted." ${ }^{84}$ A high percentage of rights-restrictive amendments involved criminal procedure, it is true, but that development is not inconsistent with what went on in the federal courts, Congress, and the state legislatures over the same period of time. ${ }^{85}$

Is it always the case, moreover, that legal guarantees, even individual rights guarantees, should be discounted because they are democratic? Is there a risk, as one scholar wonders, of becoming too obsessed with countermajoritarianism, of losing sight of the possibility that supermajority requirements are not invariably a precondition of progress and occasionally may be an impediment to it? ${ }^{86}$ Some of the landmarks in federal constitutional law no doubt represented the epitome of countermajoritarian law at the time they were issued. Brown v. Board of Education comes to mind. As does West Virginia State Board of Education v. Barnette. ${ }^{87}$ Yet one of the most significant civil rights breakthroughs in American history came not from the interpretation of a countermajoritarian guarantee but from the adoption of a majoritarian one: the Civil Rights Act of $1964 .{ }^{88}$ All things being equal, would one rather live in a country (or a state) in which a citizen consensus protects the rights of minority groups or in which a court consensus does so? That state constitutional provisions are more responsive to the will of the people at a given point in time than the Federal Constitution is not invariably a curse. ${ }^{89}$

house approve the initiative. See KAN. CONST. art. 14, § 1.

82. Galie \& Bopst, supra note 20, at 50.

83. Id. at 35 .

84. Id.

85. Id.

86. Sanford Levinson, How the United States Constitution Contributes to the Democratic Deficit in America, 55 DRAKE L. REV. 859, 869 (2007).

87. 319 U.S. 624 (1943).

88. Pub. L. No. 88-352, 78 Stat. 241 (1964) (codified as amended in 42 U.S.C. § 2000a to h-6).

89. See generally LEVINSON, supra note 41 (citing as examples of out-of-date federal constitutional provisions the citizenship-duration requirement for elected officials, judicial life tenure, and the Article $\mathrm{V}$ amendment process). 
All of this underscores the perils of generalization, whether about the ease with which state constitutions can be amended, the impact of the amendment procedures on state government, or the impact of these procedures on individual rights. The variations prove not that state constitutions as a group are too populist but instead that choosing rules for altering charters of government is complex, leading to a variety of paths for preserving lasting but relevant charters, nearly all of which add meaningful obstacles to the amendment process-obstacles that do not encumber the passage of ordinary law.

\section{JUDICIAL ELECTIONS}

State constitutions face a related critique, that the judges tasked with interpreting them are elected. This feature of most state judiciaries, the argument goes, adds a second fault line in any effort to protect individuals from their government: elected judges may lack the will to defy the majority in a given case, and even when they muster the courage, the majority may change the constitution in response.

One need not look far to find critics of judicial elections. The alleged faults are many: The fundraising demands of running for office create appearance problems; ${ }^{90}$ the courts were designed to be the nonpolitical branch of government, making it odd to select judges through the ballot box; ${ }^{91}$ the electorate lacks sufficient information to choose judges effectively; ${ }^{92}$ and popularly elected judges are unwilling to protect unpopular groups, particularly those charged with crime. ${ }^{93}$ If Justice O’Connor, who was herself a state court judge and who spent twenty-six years reviewing the work of the state supreme courts, thinks contested judicial elections are unsound, perhaps that is reason enough to listen. ${ }^{94}$ The same goes for the like-minded criticisms of Chief Justice Moyer of

90. See Deborah Goldberg, Public Funding of Judicial Elections: The Roles of Judges and the Rules of Campaign Finance, 64 OнIо ST. L.J. 95, 95 (2003); Lawrence Lessig, What Everybody Knows and What Too Few Accept, 123 HARV. L. REV. 104, 104-06 (2009).

91. See Sandra Day O’Connor, "Choosing (and Recusing) Our State Court Justices Wisely": Keynote Remarks by Justice O’Connor, 99 GEO. L.J. 151, 151-52 (2010).

92. See Charles Gardner Geyh, The Endless Judicial Selection Debate and Why It Matters for Judicial Independence, 21 GEO. J. LEGAL ETHICS 1259, 1270 (2008).

93. See Jed Handelsman Shugerman, The Twist of Long Terms: Judicial Elections, Role Fidelity, and American Tort Law, 98 GEO. L.J. 1349, 1404 (2010).

94. See Sandra Day O’Connor, Op.-Ed., The Threat to Judicial Independence, WALL ST. J., Sept. 27, 2006, at A18; see also Paul J. De Muniz, Politicizing State Judicial Elections: A Threat to Judicial Independence, 38 WillametTE L. REV. 367, 368 (2002); Joseph E. Lambert, Contestable Judicial Elections: Maintaining Respectability in the Post-White Era, 94 KY. L.J. 1, 10 (2005). 
the Ohio Supreme Court, a highly respected state jurist who presided over that court for twenty-four years. ${ }^{95}$

Others wonder what is wrong with allowing the people of a state to respond to judicial decisions they do not like. ${ }^{96}$ They argue that judicial elections are democratic, establish accountability, and limit overreaching by the judiciary, adding that a system of political appointments does not necessarily produce better-or more impartial-judges. ${ }^{97}$ And as election defenders frequently point out, many people like having the choice. $^{98}$

No matter how strongly one criticizes or defends judicial elections, the impact of them on state constitutional law should not be overstated. It is true that eighty-seven percent of the state judges throughout the country must face the electorate at regular intervals. ${ }^{99}$ But just as the states' methods of constitutional reform vary, so do their methods of judicial selection. ${ }^{100}$

Twelve states do not use popular elections to select or retain judges for their highest courts. ${ }^{101}$ Twenty-six states rely on the governor to nominate or appoint judges. ${ }^{102}$ Eight states include the legislature in a confirmation process, ${ }^{103}$ while two rely on a government-created council to approve or nominate candidates. ${ }^{104}$ In Virginia and South Carolina, the governor plays no formal role, and the legislature selects the judges. ${ }^{105}$ While most of these states provide fixed terms of office

95. Thomas J. Moyer, From Kiev to Columbus: A Perspective on Judicial Independence, 82 IND. L.J. 1235, 1235 n.*, 1236 (2007).

96. See, e.g., John Blume \& Theodore Eisenberg, Judicial Politics, Death Penalty Appeals, and Case Selection: An Empirical Study, 72 S. CAL. L. ReV. 465, 488 (1999); William B. Rubenstein, The Myth of Superiority, 16 Const. Comment., 599, 619-20 (1999); William H. Pryor, Jr., Neither Force nor Will, but Merely Judgment, WALL ST. J., Oct. 4, 2006, at A14.

97. See Michael DeBow et al., The Case for Partisan Judicial Elections, 33 U. ToL. L. Rev. 393, 396, 399 (2002).

98. See, e.g., Editorial, Mixed Signals: People Want to Elect Judges but Don't Know Them, BIRMiNGHAM NeWS, Mar. 26, 2000, at 2C.

99. Wilkinson, supra note 8, at 566.

100. See generally Caleb Nelson, A Re-evaluation of Scholarly Explanations for the Rise of the Elective Judiciary in Antebellum America, 37 AM. J. LEGAL HIST. 190 (1993) (offering an historical analysis of why most states moved from appointments to elections of their judges).

101. See Devins, supra note 20, at 1645-47; Methods of Judicial Selection, AM. JudiCATURE SoC’Y, http://www.judicialselection.us/judicial_selection/methods/selection_of_judges.cfm (last visited Feb. 16, 2011).

102. See Devins, supra note 20, at 1645-47; Methods of Judicial Selection, supra note 101.

103. Connecticut, Delaware, Hawaii, Maine, New Jersey, New York, Rhode Island, and Vermont. See Methods of Judicial Selection, supra note 101.

104. These two are Massachusetts and New Hampshire. See id.

105. See id. 
ranging from six to fourteen years, ${ }^{106}$ four do not. Massachusetts and New Hampshire allow judges, once appointed, to serve until age seventy. ${ }^{107}$ In New Jersey, once judges have been reappointed after an initial seven-year term, they may serve until seventy. ${ }^{108}$ After appointment, judges in Rhode Island enjoy life tenure. ${ }^{109}$

Judges in eighteen states face retention elections but are not initially selected through elections. Whether appointed by the state's governor, a nominating commission, or some other body, judges in these states face what amounts to popular reappointment votes, as they are the only individuals on the ballot. ${ }^{110} \mathrm{~A}$ high percentage of judges win these elections, ${ }^{111}$ and these contests usually do not impose heavy, if any, fundraising demands on judges. ${ }^{112}$ Recently, there have been notable exceptions to the contrary, and perhaps they suggest a trend. ${ }^{113}$ Yet, historically, there has been considerable support for this approach to balancing judicial independence and accountability. ${ }^{114}$

Two states, Illinois and Pennsylvania, combine retention elections with more traditional elections in selecting their judges. They fill vacancies through contested elections, then require the judges to win periodic retention elections to stay on the court. ${ }^{115}$

106. Compare VT. Const. ch. II, $\S 34$ (showing the term for Vermont judges is six years), with N.Y. CONST. art. VI, § 2 (showing the term length for New York judges is fourteen years).

107. MASS. CONST. amend. art. XCVIII; N.H. CONST. pt. 2, art. 73, 78.

108. N.J. CONST. art. VI, § VI, $\uparrow 3$.

109. See R.I. CONST. art. X, § 5.

110. Devins, supra note 20, at 1645-47. For its supreme court and court of appeals, Tennessee also uses appointments and retention elections. See TENN. Const. art. VI, § 3; TENN. CoDE AnN. $\S \S 17-4-112,-115,-116$ (West Supp. 2011).

111. Less than one percent of the 6306 state court judges who faced retention elections between 1964 and 2006 lost. Rachel Paine Caufield, Reconciling the Judicial Ideal and the Democratic Impulse in Judicial Retention Elections, 74 Mo. L. REV. 573, 577 (2009).

112. Between 1999 and 2006, judicial candidates in contested elections raised \$157 million, while candidates in retention elections raised only $\$ 1.5$ million. Id. at 580 .

113. In 2010, three Iowa Supreme Court justices lost their seats in retention elections. A.G. Sulzberger, Ouster of Iowa Judges Sends Signal to Bench, N.Y. TIMES, Nov. 4, 2010, at A1; see also Todd E. Pettys, Letter from Iowa: Same-Sex Marriage and the Ouster of Three Justices, 59 U. KAN. L. REV. 715 (2011). Judges in Alaska, Colorado, Kansas, Illinois, and Florida faced elections in 2010, but they were all reelected. Sulzberger, supra.

114. See Aman McLeod, If at First You Don't Succeed: A Critical Evaluation of Judicial Selection Reform Efforts, 107 W. VA. L. REV. 499, 512-13 (2005) (describing the American Judicature Society's support for retention elections); Debra Cassens Weiss, O'Connor: Want a Qualified, Impartial Judiciary? Don't Use Contested Elections, ABA J. (Dec. 10, 2009), http://www.abajournal.com/news/article/oconnor_want_a_qualified_impartial_judiciary_dont_use_c ontested_elections/ (describing Justice O’Connor's support for an appointment process with retention elections). But see G. Alan Tarr, Do Retention Elections Work?, 74 Mo. L. REV. 605 (2009) (suggesting retention elections themselves have become politicized).

115. Devins, supra note 20, at 1645. 
The remaining nineteen states select judges through contested elections in which two or more opponents may appear on the ballot. ${ }^{116}$ Of these, fifteen are handled through nonpartisan election, ${ }^{117}$ meaning that a judge's party affiliation does not appear on the ballot, while four select judges through partisan elections. ${ }^{118}$

All told, roughly three-fifths of the states (twenty-nine) do not use traditional elections to choose their judges. And of the twenty-one states that use elections in which two or more candidates may be on the ballot, only four of them involve partisan elections. Roughly eighty-five percent of incumbent state supreme court justices in open elections, whether partisan or nonpartisan, win reelection. ${ }^{119}$ More than ninetyeight percent of justices win retention elections. ${ }^{120}$ An overview of the states' approaches to judicial selection thus reveals a range of approaches-including some that roughly parallel the federal selection model—and confirms that only a discrete minority use party-based election models.

Instead of undermining state constitutional law, this diversity of judicial-selection methods confirms the difficulty of the task at hand: how to use a majoritarian process to pick candidates for a nonmajoritarian job. There is no such thing as a nondemocratic approach to picking American judges. Even the United States Constitution requires a popularly elected President to make the nominations and a popularly elected Senate to confirm them. ${ }^{121}$ Life tenure after that,

116. Id. Though Tennessee elects its trial court judges, it initially appoints supreme court justices and court of appeals judges and uses retention elections. Id. at $1646 \mathrm{n} .95$; see also TeNN. Const. art. VI, § 3; TENN. CoDE ANN. §§ 17-4-112, -114, -115, -116 (West Supp. 2011).

117. Devins, supra note 20, at 1646-47; see ARK. CONST. amend. 80, § 18; GA. CONST. art. VI, $\S$ VII, ๆ I; IDAHO CONST. art. V, § 6, art. VI, § 7; KY. CONST. §§ 117-19; MICH. CONST. art. VI, § 2; Mich. Comp. LaWs AnN. § 168.392 (West 2008); Minn. Const. art. VI, § 7; Minn. Stat. AnN. $\S \S$ 204D.08(6) (West 2008), 204D.11(6) (West 2009); MISs. ConST. art. VI, § 145; Miss. CodE AnN. § 23-15-976 (West 2003); Mont. Const. art. VII, § 8; Mont. CodE ANN. § 13-14-111 (2009); NEV. CONST. art. 6, § 3; NEv. Rev. StAT. ANN. § 293.195 (West 2008); N.C. Const. art. IV, § 16; N.C. Gen. StAT. ANN. § 163-322 (West 2007); N.D. Const. art. VI, § 7; N.D. Cent. Code AnN. § 16.1-11-08 (West 2008); OHio Const. art. IV, § 6; OHio Rev. Code AnN. $\S \S 3505.04,3513.01,3513.08$ (West 2007); OR. CONST. art. VII, § 1; OR. REV. STAT. AnN. $\S 254.005$ (8) (West 2007); WASH. CONST. art. 4, § 3; WASH. REV. CODE § 29A.52.231 (West 2005); WIs. CONST. art. VII, § 4; WIS. STAT. ANN. § 5.60 (West 2005).

118. Devins, supra note 20, at 1646-47; see ALA. CONST. art. VI, § 152; LA. CONST. art. V, $\S 22$; Tex. Const. art. V, § 2; W. VA. Const. art. VIII, § 2 (West 2002); W. VA. Code AnN. $\S 3-5-4$.

119. Chris W. Bonneau, Vacancies on the Bench: Open-Seat Elections for State Supreme Courts, 27 JUST. SYs. J. 143, 144 (2006).

120. Id.; see also Caufield, supra note 111, at 577.

121. See U.S. ConST. art. II, § 2, cl. 2. 
together with a prohibition on reducing pay, may help to insulate federal judges from politics, but the judges still must be selected at the outset by office holders who obtained a majority, not a minority, of votes.

Even if we characterize the models adopted by the federal government and twelve of the states as the most insulated from electoral politics, it is difficult to deny that those involved in the selection and confirmation process have become increasingly accountable to the electorate for their choices. A central critique of state judicial elections is the risk of "backlash" and the impact this may have on judicial decisions. ${ }^{122}$ Whatever the nature of that threat, is it not possible that federal judicial decisions over the last five decades have affected later nominations and confirmations? Many say they have. ${ }^{123}$

Critics of judicial elections, particularly those who think they make ordinary law out of constitutional law, also must account for state court decisions over the last several decades, in which elected judges granted individual-rights protections that life-tenured federal justices would not. A narrative assuming that only politically insulated judges will protect politically disfavored rights must account for a range of contrary state court decisions. When the United States Supreme Court rejected the claims that education was a fundamental right and that wealth was a suspect class in San Antonio Independent School District v. Rodriguez, ${ }^{124}$ that did not end inquiries into the constitutionality of the fifty state school-funding systems. Over the next thirty-five years, forty-five states faced state-constitutional challenges to their funding programs, and twenty-eight of the states, Texas included, chose to grant relief that the federal court would not. ${ }^{125}$

A similar story is unfolding in the aftermath of Kelo v. City of New London. ${ }^{126}$ After the U.S. Supreme Court allowed the states to continue to defeat takings claims through broad conceptions of eminent-domain

122. See Devins, supra note 20, at 1654-74.

123. See, e.g., Benjamin Wittes, Confirmation WARs: Preserving Independent Courts IN ANGRY TIMES 10-14 (2006); Sheldon Goldman, Judicial Confirmation Wars: Ideology and the Battle for the Federal Courts, 39 U. RICH. L. REV. 871, 874-78 (2005); Lori A. Ringhand, In Defense of Ideology: A Principled Approach to the Supreme Court Confirmation Process, 18 WM. \& MARY BILl RTS. J. 131, 166-71 (2009); David R. Stras, Understanding the New Politics of Judicial Appointments, 86 TEX. L. REV. 1033, 1057-72 (2008); see generally JAN CRAWFORD GREENBURG, SuPREME CONFLICT: THE INSIDE STORY OF THE STRUGgLE FOR CONTROL OF THE UNITED STATES SUPREME COURT (2007).

124. 411 U.S. 1 (1973).

125. See Jeffrey S. Sutton, San Antonio Independent School District v. Rodriguez and Its Aftermath, 94 VA. L. REV. 1963, 1974-76 (2008).

126. 545 U.S. 469 (2005). 
"public use," the states insisted on change, whether through state court decisions or state legislative initiatives. ${ }^{127}$ More than half of the states so far have granted relief that Kelo would not. ${ }^{128}$

Employment Division v. Smith ${ }^{129}$ tells a similar story. After Smith held that neutral, generally applicable laws trigger rational basis, not strict scrutiny, review of free exercise claims, ${ }^{130}$ many states assessed the issue for themselves, as Smith indeed contemplated they could. Since Smith, twelve state supreme courts have held that their constitutions provide greater protection for free exercise of religion. ${ }^{131}$ On top of this, thirteen states have adopted legislative religious freedom protections. ${ }^{132}$ All of this, moreover, came at the same time Congress was passing similar legislation at the national level, first through the Religious Freedom Restoration Act of $1933^{133}$ and eventually through the Religious Land Use and Institutionalized Persons Act of $2000 .^{134}$ Even in the criminal procedure arena, case books can be filled with state court decisions opting to grant relief that the United States Supreme Court would not. ${ }^{135}$

127. See Sutton, supra note 125 , at 1984-85.

128. See Steven J. Eagle \& Lauren A. Perotti, Coping with Kelo: A Potpourri of Legislative and Judicial Responses, 42 REAL PROP. PROB. \& TR. J. 799, 803, 829-45 (2008).

129. 494 U.S. 872 (1990).

130. Id. at 884-91.

131. See Daniel A. Crane, Beyond RFRA: Free Exercise of Religion Comes of Age in the State Courts, 10 St. Thomas L. Rev. 235, 245-47 (1998); see also Huffman v. State, 204 P.3d 339, 344 (Alaska 2009); Swanner v. Anchorage Equal Rights Comm'n, 874 P.2d 274, 280-81 (Alaska 2009); City of Chapel Evangelical Free Inc. v. City of South Bend, 744 N.E.2d 443, 445-46 (Ind. 2001); State v. Van Winkle, 889 P.2d 749, 754-55 (Kan. 1995); Rupert v. City of Portland, 605 A.2d 63, 66 (Me. 1992); Kolodziej v. Smith, 588 N.E.2d 634, 637 (Mass. 1992); Soc’y of Jesus v. Boston Landmarks Comm'n, 564 N.E.2d 571, 573 (Mass. 1990); State v. Hershberger, 462 N.W.2d 393, 396-97 (Minn. 1990); State v. French, 460 N.W.2d 2, 8-9 (Minn. 1990); St. John’s Lutheran Church v. State Comp. Ins. Fund, 830 P.2d 1271, 1276-77 (Mont. 1992); Palmer v. Palmer, 545 N.W.2d 751, 755 (Neb. 1996); Catholic Charities of Diocese of Albany v. Serio, 859 N.E.2d 459, 465-67 (N.Y. 2006); Humphrey v. Lane, 728 N.E.2d 1039, 1043 (Ohio 2000); Hunt v. Hunt, 648 A.2d 843, 850 (Vt. 1994); First Covenant Church of Seattle v. City of Seattle, 840 P.2d 174, 182-83 (Wash. 1992).

132. See Eugene Volokh, A Common-Law Model for Religious Exemptions, 46 UCLA L. REV. 1465, 1468 (1999); see also ARIZ. ReV. StAT. AnN. § 41-1493 (2010); Conn. GEN. STAT. AnN. $\S 52-571 b$ (West 2005); FLA. STAT. ANN. §§ 761.01-05 (West 2010); IDAHO CodE ANN. §§ 73-401-404 (West 2006); 775 ILl. Comp. StAT. AnN. 35/1-99 (West 2010); Mo. AnN. STAT. §§ 1.302-307 (West 2011); N.M. STAT. ANN. §§ 28-22-1-5 (West 2003); OKLA STAT. ANN. tit. 51, $\S \S$ 251-58 (West 2008); 71 PA. CONS. STAT. §§ 2401-2407 (2010); R.I. GEN. LAWS ANN. §§ 42-80-1-4 (West 2006); S.C. CoDE ANN. §§ 1-32-10-60 (2005); TEX. CiV. PrAC. \& REM. CODE ANN. §§ 110.001-012 (West 2005); VA. CoDE ANN. § 57-1 (West 2009).

133. Pub. L. No. 103-141, 107 Stat. 1488 (1993) (codified as amended at 42 U.S.C. §§ 2000bb to bb-4).

134. Pub. L. No. 106-274, 114 Stat. 803 (2000) (codified at 42 U.S.C. §§ 2000cc to cc-5).

135. See generally State v. Marsala, 579 A.2d 58 (Conn. 1990) (finding that the good-faith 
What if we switch from landmark federal constitutional decisions that deny relief to decisions that grant relief? Did the National Supreme Court march alone or were the state and federal courts traveling similar paths or at least borrowing from each other in the process?

Brown v. Board of Education, ${ }^{136}$ perhaps the most prominent example of federal judicial relief in the face of recalcitrant states, paints a complicated picture. The companion case to Brown, Bolling $v$. Sharpe ${ }^{137}$ involved the segregated schools of the District of Columbia, a federal enclave that no state court or legislature could reach. And the "separate but equal" defense raised in both Brown and Bolling was one of the U.S. Supreme Court's own making. ${ }^{138}$ Before Brown, seventeen states, like the District of Columbia, segregated their schools, sixteen prohibited segregation in schools, four allowed local districts to decide the matter, and eleven had no laws on the subject. ${ }^{139}$

Mapp $v$. Ohio $^{140}$ and the development of the exclusionary rule involved a state-federal judicial partnership that continues to this day. Several state courts innovated the rule around the turn of the twentieth century. ${ }^{141}$ The United States Supreme Court embraced the rule for federal law enforcement in 1914 in Weeks v. United States. ${ }^{142}$ By 1949, when the Supreme Court refused to extend Weeks to the states through incorporation, ${ }^{143}$ sixteen states had adopted their own exclusionary rules. ${ }^{144}$ And by 1961, when Mapp extended the rule to the states, over half of the states had embraced the rule on their own, a point Mapp itself

exception to the exclusionary rule recognized by the U.S. Supreme Court did not exist under Connecticut law); Bryan v. State, 571 A.2d 170 (Del. 1990) (affording greater protections under Delaware's version of the Sixth Amendment right to counsel than those under the Federal Constitution); Commonwealth v. Mavredakis, 725 N.E.2d 169 (Mass. 2000) (recognizing greater state constitutional privileges against compelled self-incrimination than under federal law); People v. Bullock, 485 N.W.2d 866 (Mich. 1992) (recognizing greater protection under Michigan law against "cruel and unusual" punishment than under federal law); Robert F. Williams, In the Glare of the Supreme Court: Continuing Methodology and Legitimacy Problems in Independent State Constitutional Rights Adjudication, 72 Notre DAme L. Rev. 1015, 1017 (1997) (“Tallies are periodically made and updated of the numbers of cases in which state courts have, under their own constitutions, recognized rights beyond those in the Federal Constitution. Most of us have stopped counting.") (citation omitted).

136. 347 U.S. 483 (1954).

137. 347 U.S. 497, 498 (1954).

138. See Plessy v. Ferguson, 163 U.S. 537, 551-52 (1896).

139. Robert L. Hayman, Jr. \& Nancy Levit, The Constitutional Ghetto, 1993 WIS. L. REV. 627, 666 \& n. 177

140. 367 U.S. 643 (1961).

141. See Blocher, supra note 34, at 372 n.255.

142. 232 U.S. 383, 398 (1914), overruled by Mapp, 367 U.S. 643.

143. See Wolf v. Colorado, 338 U.S. 25, 33 (1949), overruled by Mapp, 367 U.S. 643.

144. Blocher, supra note 34 , at 372. 
acknowledged in opting not to follow its earlier non-incorporation decision. ${ }^{145}$ On this historical slate, it is no overstatement to conclude that the Court "relied on the states not just as independent expositors of constitutional values, but as laboratories whose practical experience with constitutional rules was enlightening." 146 Nor is the "dialogue" over. Since the Court developed an exception to the exclusionary rule for officers who rely in good faith on the existence of a warrant in United States $v$. Leon, ${ }^{147}$ twenty state courts have declined to apply the Leon good-faith exception under their own constitutions. ${ }^{148}$

District of Columbia v. Heller ${ }^{149}$ followed a course that most of the state courts had charted. Before interpreting the Second Amendment to protect an individual right to bear arms-as opposed to a collective right-most of the state courts had already ruled the same way under their own constitutions. Forty-four state constitutions protect the right to keep and bear arms, and thirty-nine of the courts in those states had interpreted these provisions to protect an individual right to keep arms before Heller. ${ }^{150}$ The lone exception is Massachusetts, which has held that its provision protected a collective right rather than an individual right. ${ }^{151}$ Kansas, whose court had formerly held that the right to bear arms was a collective one, ${ }^{152}$ amended its constitution last year to make it clear that the right is individual. ${ }^{153}$ Hawaii and Virginia have not addressed the issue. ${ }^{154}$

The point of this discussion is not to laud or lament these decisions. It is to reveal the risk of generalizing about the impact of judicial elections on state constitutional law and still more so on the future of state constitutional law. As with the impact of majoritarian amendment procedures, the election story is a complex and nuanced one. Here too we have a conundrum-finding a democratic way to pick people for a

\footnotetext{
145. Mapp, 367 U.S. at 651; Blocher, supra note 34, at 372-73.

146. Blocher, supra note 34 , at 373.

147. 468 U.S. 897, 926 (1984).

148. Blocher, supra note 34 , at 373 . Professor Blocher describes similar state-federal partnerships in the development of other federal constitutional claims, including the actual-malice test under the First Amendment, the right to counsel under the Sixth Amendment, and the prohibition of race and gender discrimination in jury selection. Id. at 370-75.

149. 554 U.S. 570 (2008).

150. Eugene Volokh, State Constitutional Rights to Keep and Bear Arms, 11 Tex. ReV. L. \& POL. 191, 192, 205-06 (2006).

151. Id. at 205.

152. See City of Salina v. Blaksley, 83 P. 619, 620 (Kan. 1905).

153. KAN. CONST. Bill of Rights $\S 4$.

154. See Volokh, supra note 150, at 205.
} 
nonmajoritarian job-and here too we have a range of state and federal experiences in responding to the problem, with many chapters of the story still left to be told.

\section{LOCKSTEP INTERPRETATIONS}

Some state courts diminish their constitutions by interpreting them in lockstep with the Federal Constitution, ${ }^{155}$ occasionally at the beck and call of the state constitution itself. ${ }^{156}$ The issue arises when the Federal Constitution and a state constitution contain an identical or similarly worded guarantee and a litigant invokes both of them, by arguing, say, that an arrest violates the federal and state prohibitions on "unreasonable searches and seizures."157 There is no reason to think, as an interpretive matter, that constitutional guarantees of independent sovereigns, even guarantees with the same or similar words, must be construed the same. Still less is there reason to think that a highly generalized guarantee, such as a prohibition on "unreasonable" searches, would have just one meaning for a range of differently situated sovereigns. Yet in my experience, state and federal courts frequently handle such cases by considering the federal constitutional claim first, after which they summarily announce that the state provision means the same thing. ${ }^{158}$

155. See Blocher, supra note 34, at 339 ("To this day, most state courts adopt federal constitutional law as their own. Bowing to the nationalization of constitutional discourse, they 'tend to follow whatever doctrinal vocabulary is used by the United States Supreme Court, discussed in the law reviews, and taught in the law schools."” (quoting Hans A. Linde, E. PluribusConstitutional Theory and State Courts, 18 GA. L. REV. 165, 186 (1984))).

156. See FLA. Const. art. I, §§ 12, 17 (requiring that Florida courts construe the state constitutional right against unlawful searches, seizures, and excessive punishments "in conformity with" the Fourth and Eighth Amendments, respectively, as interpreted by the U.S. Supreme Court); cf. CAL. CONST. art. I, § 7(a) ("A person may not be... denied equal protection of the laws; provided, that nothing... imposes upon the State... any obligations or responsibilities which exceed those imposed by the Equal Protection Clause of the 14th Amendment to the United States Constitution with respect to the use of pupil school assignment or pupil transportation.”); Raven v. Deukmejian, 801 P.2d 1077, 1089 (Cal. 1990) (striking down a section of Proposition 115 that prevented state courts from construing the California constitution to afford greater rights to criminal defendants than the Federal Constitution).

157. U.S. CONST. amend. IV; see also, e.g., MICH. CONST. art. 1, § 11; N.J. Const. art. I, § 7.

158. See, e.g., State v. Jenkins, 3 A.3d 806, 839 (Conn. 2010) (holding that "the Connecticut constitution does not provide criminal defendants with greater protections than does the federal constitution in the context of unrelated questioning, including requests for consent to search, made during routine traffic stops”); State v. Stevens, 367 N.W.2d 788, 796-97 (Wis. 1985) (holding that search of garbage did not violate Wisconsin or Federal Constitutions); see also People v. Collins, 475 N.W.2d 684, 691 (Mich. 1991) (stating that the Michigan constitutional provision prohibiting "unreasonable searches and seizures" should "be construed to provide the same protection as that secured by the Fourth Amendment, absent 'compelling reason' to impose a different interpretation.”); State ex rel. Rear Door Bookstore v. Tenth Dist. Court of Appeals, 588 N.E.2d 116, 
Why the meaning of a federal guarantee proves the meaning of an independent state guarantee is rarely explained and often seems inexplicable. If the court decisions of another sovereign ought to bear on the inquiry, those of a sister state should have more to say about the point. State constitutions are more likely to share historical and cultural similarities. They necessarily will cover smaller jurisdictions. And in almost all instances they will be construing individual-liberty guarantees that originated in state constitutions, not the Federal Constitution, ${ }^{159}$ and they indeed will be exercising a power-judicial review - that originated in state constitutional law, not in Marbury v. Madison. ${ }^{160}$

Why borrow in particular from the larger, far larger, jurisdiction? Federalism considerations may lead the United States Supreme Court to underenforce (or at least not to overenforce) constitutional guarantees in view of the number of people affected (over 300 million) and the range of jurisdictions implicated (one national government, fifty states, and thousands of local governments). ${ }^{161}$ No state supreme court, by contrast, has any reason to apply a "federalism discount" to its decisions, ${ }^{162}$ making it odd for state courts to rely exclusively on the meaning of the Federal Constitution in construing their own.

State court decisions of this type not only seem to be prioritizing the wrong decisions in determining the meaning of their own constitutions, but they also seem to be inverting the right sequence for considering state and federal arguments. Federal constitutional avoidance principles would suggest that the state guarantee ought to be considered first. If the

123 (Ohio 1992) (declining to find greater free speech guarantees in the Ohio Constitution than the Federal Constitution); In re F.C. III, 2 A.3d 1201, 1212 (Pa. 2010) (“[W]e find the due process rights implicated herein under our Constitution to be equal to those under the Fourteenth Amendment of the United States Constitution.”); cf. Am. Atheists, Inc. v. City of Detroit Downtown Dev. Auth., 567 F.3d 278, 301 (6th Cir. 2009) (holding that, under Michigan law, the establishment clauses of the Michigan and Federal Constitutions are interpreted the same way).

159. See, e.g., William J. Brennan, Jr., State Constitutions and the Protection of Individual Rights, 90 HARV. L. REV. 489, 501 (1977) ("Prior to the adoption of the federal Constitution, each of the rights eventually recognized in the federal Bill of Rights had previously been protected in one or more state constitutions.”); Randy J. Holland, State Constitutions: Purpose and Function, 69 TEMP. L. REV. 989, 997 (1996) ("[S]tate Declarations of Rights were the primary origin and model for the provisions set forth in the Federal Bill of Rights.”); Gordon S. Wood, Foreword: State ConstitutionMaking in the American Revolution, 24 RUTGERS L.J. 911, 911 (1993) ("The office of our governors, the bicameral legislatures, tripartite separation of powers, bills of rights, and the unique use of constitutional conventions were all born during the state constitution-making period between 1775 and the early 1780s, well before the federal constitution of 1787 was created.”).

160. Blocher, supra note 34, at 334.

161. See Alexandra Natapoff, Underenforcement, 75 FORDHAM L. REV. 1715, 1747 (2006); Lawrence Gene Sager, Fair Measure: The Legal Status of Underenforced Constitutional Norms, 91 HARV. L. REV. 1212, 1218, 1248 (1978); see also Sutton, supra note 125, at 1978-79.

162. Sutton, supra note 125, at 1979. 
state supreme court grants relief to the claimant on the state ground and provides a clear statement that it is doing so, ${ }^{163}$ the case is over, and the need to construe the federal constitutional provision disappears with it. ${ }^{164}$ No version of the constitutional avoidance doctrine to my knowledge says that courts should consider the claim arising from the larger sovereign before they consider the claim arising from the smaller one.

The nature of a federal constitutional claim points in the same direction. At issue is whether state action violates the Federal Constitution. If the state constitution prohibits the law or conduct at issue, however, there is no work for the Federal Constitution to do. ${ }^{165}$ Why not consider that point first, not as a matter of exhaustion, but as a matter of potentially eliminating any ultra vires state action at all and sparing the need to consider the federal claim in the process? By deciding the federal claim first, state courts engage in federal constitutional aggrandizement, not avoidance, and they risk diminishing their state constitutions in the process. By doing the reverse, they claim the rightful independence of their state constitutions.

In defense of the state (and federal) courts that take this path, explanations abound. As a matter of history, state constitutional law may have been all that mattered in the country's first 150 years, at least from the perspective of an individual-rights claimant. ${ }^{166}$ But the incorporation of most of the Bill of Rights beginning in the 1920s started to change that, and the expansion of federal constitutional protections in the 1950s and 1960s completed the transformation. After the breakthroughs of the Warren Court revolution, who could blame state courts and advocates for relegating state constitutional claims to second-class treatment, if indeed to any treatment at all? A tradition of jurisprudence premised on the predominance of federal rights may not be easy to undo. Even though twenty-first century state courts are as apt to be constitutional innovators as federal courts, ${ }^{167}$ decades of state court precedents remain on the books paralleling the federal precedents or at least starting their analyses with them.

163. See Michigan v. Long, 463 U.S. 1032 (1983).

164. See Ohio v. Robinette, 519 U.S. 33, 37 (1996); Long, 463 U.S. at 1041-42.

165. See State v. Kennedy, 666 P.2d 1316, 1318 (Or. 1983) (Linde, J.); see also Hans A. Linde, E Pluribus-Constitutional Theory and State Courts, 18 GA. L. REv. 165, 176 (1984).

166. See generally Barron ex rel. Tiernan v. Mayor of Baltimore, 32 U.S. (7 Pet.) 243 (1833) (declining to apply Fifth Amendment as a limitation on the states).

167. Cf. Brennan, supra note 159, at 491; Stanley Mosk, State Constitutionalism: Both Liberal and Conservative, 63 TEX. L. REV. 1081, 1093 (1985). 
Efficiencies also may make a difference. Keep in mind that, by one count, ninety-five percent of the disputes resolved by courts in this country are filed in the state courts, as opposed to the federal ones. ${ }^{168}$ Just one of those courts, the California Supreme Court, resolved thirtyseven state constitutional law disputes in 2005, while the United States Supreme Court resolved thirty federal constitutional law disputes that same year. ${ }^{169}$ All of this makes it understandable that state courts would keep up with their burgeoning dockets by sticking to the calf-path rather than diverging from it. ${ }^{170}$

Also daunting is the reality, at least the one I have experienced, that many advocates do not press the state arguments on an independent basis. What is argued is not a ground-up assessment of the independent meaning of the state guarantee, premised on its language, its history, or early understandings of its meaning. The point urged instead is that the state courts should construe the state guarantee differently because they can, not because they must, or because the dissent rather than the majority in a U.S. Supreme Court case has the better of the (federal) arguments.

This is the one respect in which Justice Brennan's boundary-crossing 1977 article ${ }^{171}$ delivered less than it could have for the development of state constitutional law. With the waning of civil rights victories brought by the end of the Warren Court and the beginning of the Burger Court, Justice Brennan pressed the state courts to fortify the breach, to grant relief by another name: a state constitution. ${ }^{172}$ "It may not be wide of the mark," he said, "to suppose that ... state courts discern, and disagree with, a trend in recent opinions of the United States Supreme Court to pull back from, or at least suspend for the time being, the ... application of the federal Bill of Rights and the restraints of the due process and equal protection clauses of the fourteenth amendment."173 State courts, he thus urged, "cannot rest when they have afforded their citizens the full protections of the federal Constitution," but should grant relief under their own constitutions instead. ${ }^{174}$

\footnotetext{
168. George, supra note 66, at 1515.

169. Devins, supra note 20, at 1635.

170. See Sam Walter Foss, The Calf-Path, in Whiffs From Wild Meadows 77, 79-80 (1895) ("For men are prone to go it blind / Along the calf-paths of the mind, / And work away from sun to sun / To do what other men have done.").

171. See Brennan, supra note 159.

172. Id. at 490-91.

173. Id. at 495 .

174. Id. at 491 .
} 
In one respect, Justice Brennan was right. Constitutional claimants should prefer two arrows in their quiver - two chances, not just one, to invalidate a state or local law. But the messenger and the message may have helped to perpetuate, if not to create, two damaging myths.

The messenger may have prompted state court advocates and judges to misperceive this option as designed only to be a liberal ratchet, to give just some rights but not others a second chance in the state courts. Yet as shown above, independent state courts (and legislatures) often have protected a range of rights, whether involving liberty, equality, or property, whether before or after the federal courts entered the picture. That the state constitutions provide a second avenue for invalidating a local law says nothing about what kind of law should be, or will be, challenged. ${ }^{175}$

The message pushed one feature of state constitutional law (the authority of the states to construe their constitutions differently) at the expense of another (an independent basis for doing so). The suggested inquiry was not whether state constitutional law demanded a different answer from federal constitutional law based on language, context, and history; it was that, if there is a will, there is now a new way for granting relief. ${ }^{176}$ Instead of urging first-principle inquiries into the meaning of the state provisions, the article urged state courts to side with the dissenters in debates already held at the United States Supreme Courtunder federal law no less. ${ }^{177}$ While state court judges and advocates assuredly have the authority to invoke dissents rather than majority opinions of the United States Supreme Court in construing their own constitutions, heavy reliance on debates about the meaning of a federal guarantee are not apt to dignify the state constitutions as independent sources of law.

175. See Blocher, supra note 34, at 338 (noting than an interest in independent state constitutional interpretation is not "confined to liberals" and need not be justified solely on "outcome oriented” grounds); see also Randall T. Shepard, The Maturing Nature of State Constitution Jurisprudence, 30 VAL. U. L. REV. 421, 421 (1996) (“[T]he continuing strength of this movement does not derive from a desire to continue, at the state level, the agenda of the Warren-Brennan Court. It derives from the aspiration of state court judges to be independent sources of law.”).

176. See Brennan, supra note 159, at 491, 495-96.

177. See id. at 498-502; see also Blocher, supra note 34, at 337 ("Led by Justice Brennan ... liberals urged state courts to 'step into the breach' left by the Burger Court's 'contraction of federal rights and remedies on grounds of federalism.'” (quoting William J. Brennan, Jr., The Bill of Rights and the States: The Revival of State Constitutions as Guardians of Individual Rights, 61 N.Y.U. L. REV. 535, 548 (1986))); Shepard, supra note 175, at 422 (suggesting that after "Justice Brennan began to find himself on the losing end of [individual rights] cases," he "candidly announced that the war should be waged on another front”). 
The Brennan article thus helped advance state constitutional law in one sense: by reminding advocates, through a prominent Supreme Court Justice, that once-forgotten state constitutional protections remain on the books and that they provide an alternative theory for relief. But in a state constitutional law equivalent of Stockholm syndrome, the article may have advanced the unfortunate myth that federal constitutional law remains front and center-the first line of inquiry-leaving state constitutional law as the quintessential argument of last resort.

Some say that federal claims should be resolved first in cases presenting federal and state contentions because state courts cannot construe their constitutions to offer less protection than the federal guarantee. ${ }^{178}$ That is wrong. State courts remain free to construe their constitutional guarantees to offer as little protection as they think appropriate, and only a constitutional amendment can alter that decision. Some state courts have said as much. ${ }^{179}$ The only thing state courts cannot do is ignore the independent federal claim. It may be true that a state constitutional ruling that asks less of the government than existing federal constitutional law requires will not impact the parties before the court. But that is not a moot point. Once a state court establishes the interrelation between the two guarantees, it has established that no state constitutional inquiry is needed, a not-unhelpful development for future litigants and courts.

That also is a not-insignificant development for the United States Supreme Court, as it manages and assesses decisions of its own. Some state court rulings directly implicate the meaning of a federal guarantee, such as the Eighth Amendment's prohibition on "cruel and unusual punishment." 180 And some state court rulings may help to inform the original meaning of language in the Federal Constitution that first appeared in the state constitutions or may provide pragmatic reasons for following or steering clear of an approach embraced by the states. ${ }^{181}$ Why live in a "top-down constitutional world" when we have the option

178. See, e.g., Commonwealth v. Chase, 960 A.2d 108, 117 (Pa. 2008); State v. Colosimo, 669 N.W.2d 1, 10 n.2 (Minn. 2003); State v. Cline, 617 N.W.2d 277, 285 (Iowa 2000).

179. See e.g., State v. Kennedy, 666 P.2d 1316, 1323 (Or. 1983) (“A state’s view of its own guarantee may indeed be less stringent, in which case the state remains bound to whatever is the contemporary federal rule.”).

180. See Roper v. Simmons, 543 U.S. 551, 574 (2005); Atkins v. Virginia, 536 U.S. 304, 312 (2002); Penry v. Lynaugh, 492 U.S. 302, 330-31 (1989); Stanford v. Kentucky, 492 U.S. 361, 369 (1989); Blocher, supra note 34, at 378.

181. See District of Columbia v. Heller, 554 U.S. 570, 580 n.6, 583 n.7, 584-86, 590 n.13 (2008); New York Times Co. v. Sullivan, 376 U.S. 254, 280 (1964); Davis v. Massachusetts, 167 U.S. 43 (1897); Blocher, supra note 34, at 371, 382. 
of allowing the states to be the "vanguard-the first ones to decide whether to embrace or reject innovative legal claims" - and allowing the United States Supreme Court, informed by these experiences, to decide whether to federalize the issue. ${ }^{182}$ In a process that Professor Blocher calls "reverse incorporation," the United States Supreme Court remains free, whether on pragmatic or originalist grounds, to learn from and, if appropriate, borrow from the states' experiences. ${ }^{183}$

Perhaps some fear confusion in the bar if the state courts de-link the two constitutional inquiries. After all, the United States Supreme Court's multi-decade experiment with dueling standards for Bill of Rights guarantees applicable to the state and federal governments did not end well, as the Court ultimately collapsed the two. ${ }^{184}$ But is confusion really a problem for a single state? If the state courts treat the two guarantees as distinct, the bench, bar, law enforcement, and citizenry still will have to pay attention to just one standard: the more far-reaching of the two.

In the final analysis, there assuredly are historical and practical explanations for linking the meaning of federal and state guarantees and for prioritizing consideration of the federal ones. But continuing to do so in 2011 as a matter of course is increasingly difficult to justify and, worse, all the more likely to deepen the inertia-driven groove that already exists. ${ }^{185}$

\section{CONCLUSION}

To the credit of the Kansas Law Review, this symposium brings muchneeded attention to a chronically underappreciated subject: the role of the constitutions of the fifty states in American constitutionalism. An emphasis on federal constitutional law in the law schools, the academic literature, and the private bar may be an understandable, perhaps even desirable, feature of

182. Sutton, supra note 3, at 176.

183. Blocher, supra note 34, at 347-49; see also Joseph Blocher, What State Constitutional Law Can Tell Us About the Federal Constitution, 114 PENN. ST. L. REV. (forthcoming 2011) (arguing that "state doctrine[s] may be used as persuasive authority in federal cases" but may also be used "to define federal law"). Professor Blocher notes that in Mapp v. Ohio, the Supreme Court "explicitly relied on the states' independent embrace of the exclusionary rule" in deciding to incorporate it under the Fourteenth Amendment. Blocher, supra note 34, at 372; see also Mapp v. Ohio, 367 U.S. 643, 651-52 (1961).

184. See Mapp, 367 U.S. at 655-57.

185. Cf. LeARNED HAND, THE SPIRIT OF LiBERTy 241-42 (2d ed. 1954) (“[A]fter [administrative agencies] have proceeded a while they get their own sets of precedents... and they fall into grooves, just as the judges do. When they get into grooves, then God save you to get them out of the grooves.”). 
twenty-first century American law. But the all-too-frequent neglect of state constitutional law in these settings is not, unless one believes that lawyers should specialize in being half-equipped to handle constitutional matters on behalf of their clients.

In considering why state constitutional law is taken less seriously than it should be, this Essay attempts to burst some bubbles and deflate a few others. Yes, the amendment procedures and judicial elections that prevail in most states present marked contrasts with their federal counterparts. Yes, the distinction helps to explain, even sustain, the critique that the state courts frequently err on the majoritarian side of the countermajoritarian dilemma. And yes, the prolixity of the state constitutions and the frequent linkage of them to the meaning of their federal counterpart diminishes the gravity of state constitutionalism. Yet the complexity of these issues and the remarkable diversity of state approaches to them underscore the perils of dismissing state constitutional law on these grounds. After more than 200 years of experience, it is difficult to say that a consensus has emerged on the most challenging of these topics-how to select judges and how to amend constitutions-for each of this country's sovereigns, suggesting that the nation may be better off embracing fifty-one imperfect, ever-changing answers to these questions rather than just one. Through it all, American constitutionalism surely will profit from a healthy dialogue between the two systems, one spurred on by this welcome symposium. 